\title{
PENGARUH INFLASI, BI RATE, DAN NILAI TUKAR RUPIAH TERHADAP DANA PIHAK KETIGA (DPK) PADA PERBANKAN SYARIAH INDONESIA TAHUN 2012-2017
}

\section{THE EFFECT OF INFLATION, BI RATE, AND RUPIAH EXCHANGE RATE ON THIRD PARTY FUNDS (TPF) ON INDONESIAN SYARIAH BANKING IN 2012-2017}

\author{
Nofinawati \\ Fakultas Ekonomi dan Bisnis Islam IAIN Padangsidimpuan \\ Jl. T. Rizal Nurdin Km. 4,5 Sihitang 22733 \\ e-mail: nofinawati82@gmail.com
}

Naskah diterima 02 Juli 2018, di-review 01 Agustus 2018, disetujui 09 Nopember 2018

\begin{abstract}
Third Party Funds (TPF) consist of giro, savings and deposits account. The enhancement of TPF is influenced by several factors including Inflation, BI Rate, and Rupiah Exchange Rate. In 2013, there was an escalation in Inflation and the BI Rate which was not accompanied by a decrease of TPF. This is not corresponding with the theory proposed by Aulia Pohan. It is said is that if inflation increases then $T P F$ decreases. It is also not fit with Adiwarman Karim's theory of the BI Rate, that is, if there is a profit sharing of sharia funding less than the interest rate, the customer can move to a conventional bank. Whereas in 2013-2015 the Rupiah Exchange Ratedepreciated, while TPF continued to increase. This condition is also compatible with the theory given by Aulia Pohan. The existence of public expectations about the weakening of Rupiah could reduce can be collected by banks.
\end{abstract}

Keywords: inflation, BI rate, Rupiah exchange rate, deposits, Islamic banking

\begin{abstract}
Abstrak: Dana Pihak Ketiga terdiri dari giro, tabungan, dan deposito. Kenaikan Dana Pihak Ketiga dipengaruhi oleh beberapa faktor diantaranya adalah inflasi, BI rate, dan nilai tukar Rupiah. Pada tahun 2013 terjadinya peningkatan inflasi dan BI Rate yang tidak disertai dengan penurunan Dana Pihak Ketiga. Hal ini tidak sesuai dengan teori yang dikemukakan oleh Aulia Pohan tentang inflasi, apabila inflasi meningkat maka Dana Pihak Ketiga mengalami penurunan dan tidak sesuai dengan teori Adiwarman Karim tentang BI rate yaitu apabila bagi hasil pendanaan syariah lebih rendah dari tingkat bunga, maka nasabah akan pindah ke bank konvensional. Sedangkan pada tahun 2013-2015 nilai tukar Rupiah mengalami depresiasi Dana Pihak Ketiga terus mengalami peningkatan. Hal ini tidak sesuai dengan teori yang dikemukakan oleh Aulia Pohan, adanya ekspektasi masyarakat tentang melemahnya nilai Rupiah dapat mengakibatkan berkurangnya kepercayaan masyarakat terhadap Rupiah, keadaan ini akan mengurangi tersedianya dana masyarakat yang dapat dihimpun oleh perbankan. Hasil penelitian ini memiliki nilai koefisien determinasi $\left(\mathrm{R}^{2}\right)$ sebesar 0,927 artinya Inflasi, BI rate dan nilai tukar Rupiah mampu menjelaskan variasi variabel Dana Pihak Ketiga sebesar 92,7 persen. Adapun sisanya 7,3 persen dijelaskan oleh variabel lain yang tidak dimasukkan dalam penelitian ini. Hasil penelitian ini menunjukkan secara parsial menyatakan bahwa Inflasi memiliki $t_{\text {hitung }}>t_{\text {tabel }}$ atau 1,842 $>1,667$ yang artinya Inflasi berpengaruh terhadap Dana Pihak Ketiga. BI rate memiliki $-\mathrm{t}_{\text {hitung }}<-\mathrm{t}_{\text {tabel }}$ $(-11,227<-1,667)$ yang artinya BI rate berpengaruh terhadap Dana Pihak Ketiga. Nilai tukar Rupiah berpengaruh terhadap Dana Pihak Ketiga dengan $t_{\text {hitung }}>t_{\text {tabel }}(27,292>1,667)$. Inflasi, BI rate dan nilai tukar Rupiah secara simultan memiliki pengaruh yang signifikan terhadap Dana Pihak Ketiga. Hal tersebut dibuktikan dengan nilai $\mathrm{F}_{\text {hitung }}>\mathrm{F}_{\text {tabel }}(301,157>3,16)$.
\end{abstract}

Kata kunci: inflasi, BI rate, nilai tukar Rupiah, DPK, perbankan syariah 


\section{PENDAHULUAN}

Pank syariah memiliki sistem operasional Dyang berbeda dengan bank konvensional. Bank syariah memberikan layanan bebas bunga kepada para nasabahnya. Bank syariah tidak mengenal sistem bunga, baik bunga yang diperoleh dari nasabah yang meminjam uang atau bunga yang dibayar kepada nasabah penyimpan dana. Menurut jenisnya bank syariah terdiri atas Bank Umum Syariah (BUS), Unit Usaha Syariah (UUS), dan Bank Pembiayaan Rakyat Syariah (BPRS) (Ismail, 2011: 31-32).

Bank syariah memiliki 3 sumber dana yaitu dana pihak pertama yang bersumber dari para pendiri atau pemodal, dana pihak kedua yang berasal dari lembaga lainnya dan Dana Pihak Ketiga (DPK) adalah dana yang berasal dari masyarakat. Dana yang dihimpun oleh bank syariah dari masyarakat merupakan sumber dana yang terbesar bagi bank (Aruan, Skripsi 2013: 13).
Kondisi variabel makro juga berpengaruh terhadap Dana Pihak Ketiga. Kondisi ekonomi makro mempengaruhi perusahaan dan masyarakat untuk bertransaksi dengan perbankan, ketika kondisi ekonomi membaik akan meningkatkan pendapatan masyarakat yang pada akhirnya akan meningkatkan jumlah Dana PihakKetiga (Panorama,Jurnal 2016:th.). Kenaikan Dana Pihak Ketiga disebabkan oleh beberapa hal diantaranya: kondisi perekonomian masyarakat Indonesia seperti terjadinya inflasi dan melemahnya nilai tukar Rupiah, kondisi pemerintahan, kondisi pasar uang dan pasar modal, kebijakan pemerintah, peraturan Bank Indonesia seperti BI rate, dan Jumlah Uang Beredar (Rivai dan Arviyan, 2010: 573-574).

Berdasarkan data perbankan syariah di Indonesia yang dipublikasikan di website BI dan OJK, dapat dilihat perkembangan jumlah Dana Pihak Ketiga, inflasi, BI rate, dan nilai tukar rupiah dari tahun 2012-2017 yaitu terlihat dalam tabel di bawah ini:

Tabel 1

Dana Pihak Ketiga, Inflasi, BI Rate dan Nilai Tukar Rupiah

\begin{tabular}{|l|r|r|r|r|}
\hline \multicolumn{1}{|c|}{ Tahun } & DPK (dalam miliar) & \multicolumn{1}{c|}{ Inflasi } & \multicolumn{1}{c|}{ BI Rate } & \multicolumn{2}{c|}{ Nilai Tukar Rupiah } \\
\hline 2012 & $\operatorname{Rp~} 147.512$ & $4,30 \%$ & $5,75 \%$ & $\operatorname{Rp~} 9.670$ \\
\hline 2013 & $\operatorname{Rp~} 183.534$ & $8,38 \%$ & $7,50 \%$ & $\operatorname{Rp~} 12.189$ \\
\hline 2014 & $\operatorname{Rp~} 217.858$ & $8,36 \%$ & $7,75 \%$ & $\operatorname{Rp~} 12.440$ \\
\hline 2015 & $\operatorname{Rp} 231.175$ & $3,35 \%$ & $7,50 \%$ & $\operatorname{Rp~} 13.795$ \\
\hline 2016 & $\operatorname{Rp} 264.678$ & $3,02 \%$ & $5,75 \%$ & $\operatorname{Rp~} 13.436$ \\
\hline 2017 & $\operatorname{Rp} 334.719$ & $3,61 \%$ & $4,25 \%$ & $\operatorname{Rp~} 13.548$ \\
\hline
\end{tabular}

Sumber.www.bi.go.id dan www.ojk.go.id

Berdasarkan data di atas dapat dilihat adanya ketidaksesuaian antara teori dengan fenomena yang ada. Di mana pada tahun 2013 inflasi mengalami peningkatan sebesar 4,08 persen dan hal ini tidak disertai dengan penurunan Dana Pihak Ketiga. Hal ini tidak sesuai dengan teori yang menyatakan apabila inflasi meningkat maka Dana Pihak Ketiga akan mengalami penurunan.
Sama halnya dengan BI rate, dari data tersebut dapat diketahui adanya kesenjangan antara teori dengan fenomena yang ada. Di mana pada tahun 2013 dan 2014 BI rate mengalami peningkatan sebesar 1,75 persen dan 0,25 persen dan hal ini tidak diikuti dengan penurunan Dana Pihak Ketiga namun sebaliknya Dana Pihak Ketiga juga ikut mengalami peningkatan. Sedangkan

90|| Nofinawati 
dalam teori yang ada, apabila BI rate meningkat maka Dana Pihak Ketiga pada bank syariah akan mengalami penurunan.

Begitu pula dengan nilai tukar Rupiah dari data di atas dapat dilihat adanya ketidaksesuaian antara teori dengan fenomena yang ada. Di mana pada tahun 2013, 2014, 2015 nilai tukar Rupiah melemah sedangkan Dana Pihak Ketiga mengalami peningkatan.

Friska Julianti (2013) dalam penelitiannya mengatakan bahwa inflasi berpengaruh positif dan signifikan terhadap Tabungan Mudharabah, BI rate berpengaruh negatif dan signifikan terhadap Tabungan Mudharabah dan Kurs berpengaruh positif dan signifikan terhadap Tabungan Mudharabah (Friska Julianti, skripsi, 2013: 86).

Sehingga, dari pemaparan di atas peneliti menemukan adanya hal yang bertentangan dengan teori yang ada, di mana ketika inflasi, BI rate, dan nilai tukar Rupiah yang mengalami fluktuasi sedangkan Dana Pihak Ketiga selalu mengalami peningkatan. Berdasarkan dari fenomena yang ada dalam penelitian ini, peneliti tertarik untuk melakukan penelitian ini. Penelitian ini bertujuan untuk mengetahui pengaruh signifikan inflasi, BI rate, nilai tukar Rupiah terhadap Dana Pihak Ketiga baik secara parsial maupun secara simultan.

\section{Kerangka Konseptual}

\section{Dana Pihak Ketiga}

Metode penghimpunan dana yang ada pada bank konvensional didasari teori yang diungkapkan Keynes yang mengemukakan bahwa orang membutuhkan uang untuk tiga kegunaan, yaitu fungsi transaksi, cadangan, dan investasi. Oleh karena itu, produk penghimpunan dana pun disesuaikan dengan tiga fungsi tersebut, yaitu berupa giro, tabungan, dan deposito yang biasa disebut dana pihak ketiga (DPK) (Dewi, 2007: 80).

Pada bank syariah penghimpunan dana dari masyarakat dilakukan tidak membedakan nama produk tetapi melihat pada prinsip yaitu prinsip wadīah dan prinsip muḍārabah. Apapun nama produk yang diperhatikan adalah prinsip yang dipergunakan atas produk tersebut, hal ini sangat terkait dengan porsi pembagian hasil usaha yang akan dilakukan antara pemilik dana/deposan (șāhibul māl) dengan bank syariah sebagai muḍārib (Harahap, dkk, 2004: 67).

\section{Giro}

Giro Secara umum yang dimaksud dengan giro adalah simpanan yang penarikannya dapat dilakukan setiap saat dengan menggunakan cek, bilyet giro, sarana perintah bayar lainnya, atau dengan pemindahbukuan (Undang-Undang RI Nomor 10 Tahun 1998 tentang Perubahan Atas Undang-Undang Nomor 7 Tahun 1992 tentang Perbankan). Adapun yang dimaksud dengan giro syariah adalah giro yang dijalankan berdasarkan prinsip syariah dalam hal ini, Dewan Syariah Nasional telah mengeluarkan fatwa yang menyatakan bahwa giro yang dibenarkan secara syariah adalah giro yang dijalankan berdasarkan prinsip wadi'ah dan mudārabah (Karim, 2004: 265). 


\section{Giro Wadī'ah}

Giro Wadi' $a h$ adalah titipan pihak ketiga pada bank syariah yang penarikannya dapat dilakukan setiap saat dengan menggunakan cek, bilyet giro, sarana perintah pembayaran lainnya atau dengan cara pemindahbukuan (Ismail, 2011: 65). Dalam kaitannya dengan produk giro, bank syariah menerapkan prinsip Wadīah yad dhamanah, yakni nasabah bertindak sebagai penitip yang memberikan hak kepada bank syariah untuk menggunakan atau memanfaatkan uang atau barang titipannya, sedangkan bank syariah bertindak sebagai pihak yang dititipi yang disertai hak untuk mengelola dana titipan dengan tanpa mempunyai kewajiban memberikan bagi hasil dari keuntungan pengelolaan dana tersebut. Namun demikian bank syariah diperkenankan memberikan insentif berupa bonus dengan catatan tidak disyaratkan sebelumnya.

\section{Giro Mudārabah}

Giro Mudārabah adalah giro yang dijalankan berdasarkan akad mudārabah. Mudārabah mempunyai dua bentuk, yaitu mudārabah mutlaqah dan mudārabah muqayyadah, yang perbedaan utama antara keduanya terletak pada ada atau tidaknya persyaratan yang diberikan pemilik dana kepada bank dalam mengelola hartanya baik dari sisi tempat, waktu maupun objek investasinya. Dalam hal ini, bank syariah bertindak sebagai mudharib (pengelola dana), sedangkan nasabah bertindak sebagai shahibul mal (pemilik dana). Dalam kapasitasnya sebagai mudharib, bank syariah dapat melakukan berbagai macam usaha yang tidak bertentangan dengan prinsip syariah serta mengembangkannya, termasuk melakukan akad mudārabah dengan pihak lain.

Dari hasil pengelolaan dana mudārabah., bank syariah akan membagihasilkan kepada pemilik dana sesuai dengan nisbah yang telah disepakati dan dituangkan dalam akad pembukaan rekening. Dalam mengelola dana tersebut, bank tidak bertanggungjawab terhadap kerugian yang bukan disebabkan oleh kelalaiannya. Namun, apabila yang terjadi adalah mismanagement (salah urus), bank bertanggungjawab penuh terhadap kerugian tersebut.

\section{Tabungan}

Pengertian tabungan menurut UndangUndang Perbankan No. 10 Tahun 1998 dalam pasal I ayat 9 : tabungan adalah simpanan yang penarikannya hanya dapat dilakukan menurut syarat-syarat tertentu yang disepakati, tetapi tidak ditarik dengan cek, bilyet giro dan atau alat lainnya yang dipersamakan dengan itu. Sedangkan tabungan syariah adalah tabungan yang dijalankan berdasarkan prinsip-prinsip syariah. Dalam hal ini, Dewan Syariah Nasional telah mengeluarkan fatwa yang menyatakan bahwa tabungan yang dibenarkan adalah tabungan yang berdasarkan prinsip Wadī'ah danmudärabah.

\section{Tabungan Wadīah}

Tabungan Wadī'ah merupakan tabungan yang dijalankan berdasarkan akad Wadī'ah, yakni titipan murni yang harus dijaga dan dikembalikan setiap saat sesuai dengan kehendak pemiliknya. Berkaitan dengan produk tabungan Wadī'ah, bank syariah menggunakan atau memanfaatkan uang 
atau barang titipannya, sedangkan bank syariah bertindak sebagai pihak yang dititipi dana atau barang yang disertai hak untuk menggunakan dana atau barang tersebut.

\section{Tabungan Mudārabah.}

Tabungan yang menerapkan akad muḍārabah mengikuti prinsip-prinsip muḍārabah. Tabungan mudāarabah merupakan produk penghimpunan dana oleh bank syariah yang menggunakan akad muḍārabah muțlaqah. Bank syariah bertindak sebagai muḍarib dan nasabah sebagai șāhibul māl. Nasabah menyerahkan pengelolaan dana tabungan muḍārabah secara mutlak kepada mudarib (bank syariah), tidak ada batasan baik dilihat dari jenis investasi, jangka waktu, maupun sektor usaha, dan tidak boleh bertentangan dengan prinsip syariah Islam (Ismail, 2011: 98). Dalam Fatwa Dewan Syariah Nasional No. 02/DSN-MUI/IV/2000 tertanggal 1 April 2000 tentang Tabungan, memberikan landasan syariah dan ketentuan tentang tabungan mudāarabah.

\section{Deposito}

Deposito menurut Undang-Undang No. 10 Tahun 1998 tentang Perbankan dalam pasal I ayat 7 : deposito adalah simpanan berjangka yang penarikannya hanya dapat dilakukan pada waktu tertentu berdasarkan perjanjian antara nasabah penyimpan dengan bank.

Deposito menurut Undang-Undang No. 21 Tahun 2008 adalah investasi dana berdasarkan akad mudārabah atau akad lain yang tidak bertentangan dengan prinsip syariah yang penarikannya hanya dapat dilakukan pada waktu tertentu berdasarkan akad antara nasabah penyimpan dan bank syariah dan/atau UUS.

Jangka waktu deposito ini bervariasi antara lain:

1. Deposito jangka waktu 1 bulan.

2. Deposito jangka waktu 3 bulan.

3. Deposito jangka waktu 6 bulan.

4. Deposito jangka waktu 12 bulan.

5. Deposito jangka waktu $>12$ bulan.

Sebagaimana tabungan yang berdasarkan prinsip mudärabah, deposito yang menggunakan akad mudārabah juga akan mendapatkan keuntungan berupa bagi hasil atas penempatan dananya pada bank syariah sesuai dengan perjanjian yang telah disepakati nasabah dengan bank dan keuntungan yang didapatkan oleh bank.

\section{Faktor-faktor yang Mempengaruhi Dana Pihak Ketiga}

Faktor-faktor yang mempengaruhi Dana Pihak Ketiga (Rivai dan Arviyan: 2010: 573-574).

\section{Kondisi perekonomian}

Kondisi perekonomian suatu negara adalah bagaimana perkembangan perekonomian negara tersebut. Apabila perkembangan perekonomian maju pesat, berarti berdampak positif bagi dunia usaha dan pendapatan masyarakat atau perusahaan untuk menabung dan dampaknya tabungan masyarakat akan meningkat. Demikian pula jika perekonomian menurun, maka akan berdampak pada perkembangan dunia usaha yang akan lesu, tingkat pendapatan masyarakat tidak bertambah dan bahkan menurun, minat masyarakat atau perusahaan untuk menyimpan uang akan menurun, yang akan berakibat 
penghimpunan dana bank cenderung akan menurun.

\section{Kegiatan dan kondisi pemerintah}

Stabilitas pemerintahan dan kepastian hukum sangat berperan dalam menciptakan stabilitas berusaha serta jaminan dalam berusaha yang dibuktikan dengan kejelasan dan ketegasan peraturan dan kebijakan yang berlaku baik di pemerintah pusat maupun di pemerintah daerah.

\section{Kondisi atau perkembangan pasar uang dan pasar modal}

\section{Kebijakan pemerintah}

Seperti kebijakan dalam hal fiskal, pinjaman luar negeri beserta mekanisme serta syaratsyarat lainnya sangat menentukan keberhasilan bank dalam menghimpun dana. Demikian pula kebijakan pemerintah dibidang perdgangan luar negeri (ekspor impor) dan lainnya.

\section{Peraturan Bank Indonesia}

Manajemen dana sangat dipengaruhi oleh kebijkan moneter. Pengendalian moneter bertujuan untuk menjaga jumlah uang beredar dan tingkat suku bunga sehingga dapat menunjang kegiatan usaha perekonomian masyarakat di dalam kestabilan moneter serta kelancaran neraca pembayaran. Seperti: Jumlah Uang Beredar, Inflasi, BI rate dan nilai tukar Rupiah (www.bi.go.id).

\section{Inflasi}

\section{Pengertian Inflasi}

Inflasi adalah kenaikan harga barang-barang yang bersifat umum dan terus-menerus. Dari definisi ini ada tiga komponen yang harus dipenuhi agar dapat dikatakan telah terjadi Inflasi yaitu: pertama, kenaikan harga, harga suatu komoditas dikatakan naik jika menjadi lebih tinggi daripada harga periode sebelumnya. Kedua, yaitu bersifat umum, kenaikan harga suatu komoditas belum dapat dikatakan Inflasi jika kenaikan tersebut tidak menyebabkan hargaharga secara umum naik. Dan yang ketiga adalah berlangsung terus-menerus, kenaikan harga yang bersifat umum belum dikatakan inflasi jika terjadinya hanya sesaat. Karena itu, dikatakan inflasi jika terjadi dalam rentang waktu bulanan (Rahardja dan Mandala Manurung, 2008: 359360).

\section{Pengaruh Inflasi terhadap Dana Pihak Ketiga}

Laju Inflasi yang tinggi dan tidak terkendali dapat mengganggu upaya perbankan dalam pengerahan dana masyarakat. Karena tingkat Inflasi yang tinggi menyebabkan tingkat suku bunga riil menjadi menurun. Fakta demikian akan mengurangi hasrat masyarakat untuk menabung sehingga pertumbuhan dana perbankan yang bersumber dari masyarakat akan menurun. Serta kondisi ini juga dapat mengakibatkan pengaliran modal ke luar negeri. Masyarakat akan menyimpan uangnya di luar negeri (Pohan, 2008: 52). Sehingga bank akan mengalami kesusahan dalam menghimpun dana dari masyarakat ataupun yang disebut dengan Dana Pihak Ketiga.

\section{BI rate}

\section{Pengertian BI rate}

BI rate adalah suku bunga kebijakan yang mencerminkan sikap atau stance kebijakan 
moneter yang ditetapkan oleh Bank Indonesia dan diumumkan kepada publik.BI Rate diumumkan oleh Dewan Gubernur Bank Indonesia setiap Rapat Dewan Gubernur bulanan dan diimplementasikan pada operasi moneter yang dilakukan BankIndonesia melalui pengelolaan likuiditas (liquidity management)di pasar uang untuk mencapai sasaran operasional kebijakan moneter. Sasaran operasional kebiajakan moneter dicerminkan pada perkembangan suku bunga Pasar Uang Antar Bank Overnight (PUAB O/N). Bank Indonesia pada umumnya akan menaikkan BI rate apabila Inflasi diperkirakan melampaui sasaran yang telah ditetapkan, sebaliknya Bank Indonesia akan menurunkan BI rate apabila Inflasi ke depan diperkirakan berada di bawah sasaran yang telah ditetapkan (www.bi.go.id).

\section{Pengaruh BI rate terhadap Dana Pihak Ketiga}

Hubungan antara BI rate dan Dana Pihak Ketiga yaitu, meskipun bank syariah tidak menetapkan tingkat suku bunga, baik dari sisi pendanaan maupun sisi pembiayaan namun bank syariah tidak akan terlepas dari risiko suku bunga. Hal ini disebabkan pasar yang dijangkau bank syariah tidak hanya untuk nasabah-nasabah yang loyal penuh terhadap syariah. Bila terjadi bagi hasil pendanaan syariah lebih kecil dari tingkat bunga di pasar konvensional maka dapat berdampak pada peningkatan risiko likuiditas sebagai akibatnya nasabah dapat menarik dana dari bank syariah dan berpindah ke bank konvensional (Karim, 2004: 273).

\section{Nilai Tukar Rupiah}

\section{Pengertian Nilai Tukar Rupiah}

Nilai tukar mata uang atau sering disebut dengan kurs adalah harga satu unit mata uang asing dalam mata uang domestik atau dapat juga dikatakan harga mata uang domestik terhadap mata uang asing. Sebagai contoh Nilai Tukar (NT) Rupiah terhadap Dollar Amerika (USD) adalah harga satu Dollar Amerika (USD) dalam Rupiah (RP), atau dapat juga sebaliknya diartikan harga satu Rupiah terhadap satu USD.

Apabila nilai tukar didefinisikan sebagai nilai Rupiah dalam valuta asing dapat diformulasikan sebagai berikut:

$$
\begin{aligned}
\mathrm{NT}_{\text {IDR/USD }}= & \text { Rupiah yang diperlukan untuk } \\
& \text { membeli } 1 \text { Dollar Amerika (USD) } \\
\mathrm{NT}_{\text {IDR/YEN }}= & \text { Rupiah yang digunakan untuk } \\
& \text { membeli } 1 \text { Yen Jepang }
\end{aligned}
$$

Dalam hal ini, apabila NT meningkat maka berarti Rupiah mengalami depresiasi. Sedangkan apabila NT menurun maka Rupiah mengalami apresiasi (Simorangkir dan Suseno, 2004: 4). Dalam menganalisis Nilai Tukar ada juga yang disebut dengan Nilai Tukar Riil, yaitu nilai tukar nominal yang sudah dikoreksi dengan harga relatif, yaitu harga-harga di dalam negeri dibanding dengan harga-harga di luar negeri. Nilai Tukar Riil tersebut dapat dihitung dengan meggunakan rumus:

$$
\mathrm{Q}=\mathrm{S} \cdot \mathrm{P} / \mathrm{P}^{*}
$$

Dimana Q adalah Nilai Tukar Riil, S adalah nilai tukar nominal, $\mathrm{P}$ adalah harga di dalam negeri, dan $\mathrm{P}^{*}$ adalah harga barang di luar negeri (Simorangkir dan Suseno, 2004: 4). 
Kurs riil di antara kedua negara dihitung dari kurs nominal dan tingkat harga di kedua negara. Menurut N. Gregory Mankiw bahwa jika kurs riil rendah, barang-barang luar negeri relatif lebih murah, dan barang-barang domestik relatif mahal. Jika kurs riil rendah, barang-barang luar negeri relatif lebih mahal, dan barang-barang domestik relatif lebih murah (Mankiw, 2006: 130).

\section{Teori Nilai Tukar Islam}

Penyebab apresiasi dan depresiasi nilai tukar mata uang di dalam Islam dapat digolongkan dalam dua kelompok yaitu natural dan human error. Dalam pembahasan nilai tukar menurut Islam akan dipakai dua skenario yaitu: Skenario pertama: terjadi perubahan-perubahan harga di dalam negeri yang mempengaruhi nilai tukar uang (faktor luar negeri dianggap tidak berubah atau tidak berpengaruh.Skenario kedua: terjadi perubahan-perubahan harga di luar negeri (faktor di dalam negeri dianggap tidak berpengaruh atau tidak berubah.

Kebijakan nilai tukar dalam Islam dapat dikatakan menganut sistem Managed Floating, dimana nilai tukar adalah hasil kebijakan-kebijakan pemerintah karena pemerintah tidak mencampuri keseimbangan yang terjadi di pasar kecuali jika terjadi hal-hal yang mengganggu keseimbangan itu sendiri. Jadi dapat dikatakan bahwa suatu nilai tukar yang stabil merupakan hasil dari kebijakan yang tepat (Karim, 2011: 167-168.).

\section{Pengaruh Nilai Tukar Rupiah terhadap Dana Pihak Ketiga}

Adanya ekspektasi masyarakat tentang melemahnya nilai Rupiah dapat mengakibatkan berkurangnya kepercayaan masyarakat terhadap
Rupiah yang kemudian akan mendorong terjadinya spekulasi di pasar valuta asing. Keadaan ini akan mengurangi tersedianya dana masyarakat yang dapat dihimpun oleh perbankan untuk disalurkan ke sektor yang produktif (Pohan, 2008: 56).

\section{METODE PENELITIAN}

\section{Jenis Penelitian}

Jenis penelitian yang digunakan dalam penelitian ini adalah penelitian kuantitatif. Sesuai dengan namanya penelitian kuantitatif adalah data dalam angka dan lambang matematika atau dengan kata lain dapat diukur dengan skala numeric (Kuncoro, 2009: 75). Penelitian ini mengolah data sekunder yang diambil dari website Bank Indonesia (www.bi.go.id) dan website Otoritas Jasa Keuangan (www.ojk.go.id).

\section{Populasi Dan Sampel}

\section{Populasi}

Populasi adalah serumpunan atau sekelompok objek yang akan menjadi masalah penelitian (Asnawi dan Masyhuri, 2011: 117). Dalam penelitian ini yang menjadi populasinya adalah seluruh laporan Dana Pihak Ketiga, Inflasi, BI rate dan nilai tukar Rupiah dari bulan Januari sampai Desember selama tahun 2012 sampai 2017 yang berjumlah 72 bulan.

\section{Sampel}

Menurut Suharsimi Arikunto bahwa sampel adalah sebagian atau wakil dari populasi yang akan diteliti. Pengambilan sampel untuk penelitian menurut Suharsimi Arikunto, jika subjeknya kurangdari 100 sebaiknya diambil semuanya 
sehingga penelitian merupakan penelitian populasi, jika subjeknya besar atau lebih dari 100 dapat diambil 10-15 persen atau 20-25 persen atau lebih tergantung kemampuan peneliti dari berbagai segi (Arikunto, 2006: 134.). Dalam penelitian ini jumlah sampel kurang dari 100 subjek, maka peneliti mengambil semua sampel yang berjumlah 72 bulan selama tahun 2012 sampai 2017. Dan merupakan bagian Teknik sampling jenuh yaitu Teknik penentuan sampel apabila semua anggota populasi digunakan sebagai sampel.

\section{Sumber Data}

Dilihat dari segi sumber perolehan data, atau dari mana data tersebut berasal secara umum dalam peneliltian dikenal ada jenis data sekunder dan data primer. Dalam penelitian sumber data yang digunakan bersumber dari sumber data sekunder. Data sekunder adalah sumber data penelitian yang diperoleh peneliti secara tidak langsung melalui media perantara atau yanng diperoleh dan dicatat oleh instansi terkait dan pihak lain (Asnawi dan Masyhuri, 2011: 156). Adapun data sekunder yang dipakai berasal dari website resmi Bank Indonesia (www.bi.go.id) dan Otoritas Jasa Keuangan (www.ojk.go.id). Jenis data ini dapat digali melalui monografi yanng diterbitkan oleh masing-masing lembaga-lembaga tersebut, laporan-laporan, baik mingguan, bulanan, triwulan maupun tahunan, buku-buku profil, literatur, majalah-majalah dan publikasi data dari media surat kabar (Teguh, 2005: 121).

\section{Teknik Pengumpulan Data}

Teknik pengumpulan data yang digunakan pada penelitian ini adalah dengan teknik pengumpulan data dokumentasi yaitu mencari data mengenai hal-hal atau variabel yang berupa catatan, laporan, transkip, buku, surat kabar, majalah, prasasti, notulen rapat, lengger dan agenda (Arikunto, 2006: 231). Adapun data dokumentasi sebagai data pendukung yang bersumber dari data sekunder berdasarkan pada laporan keuangan publikasi Bank Indonesia dan Otoritas Jasa Keuangan.

\section{Teknik Analisis Data}

Teknik analisis data digunakan untuk menjawab rumusan masalah penelitian ataupun menguji hipotesis yang telah dirumuskan. Analisis data adalah proses mencari dan menyusun secara sistematis data yang diperoleh. Metode analisis data adalah suatu metode yang digunakan untuk mengolah hasil penelitian guna memperoleh suatu kesimpulan dalam penelitian tersebut. Adapun software yang digunakan dalam analisis data ini adalah menggunakan software SPSS versi 23 dengan bentuk regresi linear berganda merupakan teknik statistika yang dapat digunakan untuk menganalisis hubungan antara variabel dependen dengan variabel independen. Tujuan dari analisis ini adalah untuk mengetahui signifikansi pengaruh variabel independen terhadap variabel dependen, sehingga dapat memuat prediksi yang tepat (Pramesti, 2014: 113). Berhubung dalam penelitian ini variabel independen terdiri atas Inflasi, BI rate, dan nilai tukar Rupiah. Maka bentuk persamaan regresi linear berganda untuk ketiga variabel independen tersebut adalah sebagai berikut (Priyatno, 2017: 182).

$$
\mathrm{Y}=\mathrm{a}+\mathrm{b}_{1} \mathrm{X}_{1}+\mathrm{b}_{2} \mathrm{X}_{2}+\mathrm{b}_{3} \mathrm{X}_{3}
$$


Agar lebih mempermudah penelitian, maka akan dibuat dalam model yang telah disimbolkan yaitu:

$\mathrm{DPK}=\mathrm{a}+$ Inflasi b1 + BI Rate b2 + Nilai Tukar Rupiah b3

Keterangan:

$\mathrm{Y}=$ Dana Pihak Ketiga (DPK)

$\mathrm{a}=$ konstanta

$\mathrm{b}_{1,} \mathrm{~b}_{2,} \mathrm{~b}_{3}=$ koefisien regresi

$\mathrm{X}_{1} \quad=$ Inflasi

$\mathrm{X}_{2}=\mathrm{BI}$ Rate

$\mathrm{X}_{3} \quad=$ Nilai Tukar Rupiah

\section{PEMBAHASAN DAN HASIL}

\section{Deskriptif Pembahasan Penelitian}

Dari hasil peninjauan, peneliti berhasil menemukan dan mengumpulkan data Inflasi, BI Rate dan Nilai Tukar Rupiah yang bersumber dari laporan publikasi Bank Indonesia dalam website Bank Indonesia yaitu www.bi.go.id dan data Dana Pihak Ketiga yang bersumber dari laporan publikasi Otoritas Jasa Keuangan yaitu www.ojk.go.id. Data yang digunakan dalam penelitian ini yaitu data bulanan dari Dana Pihak Ketiga, Inflasi, BI Rate dan Nilai Tukar Rupiah. Oleh karena itu, peneliti akan memaparkan data yang diperoleh dari laporan publikasi yang dibutuhkan dalam laporan ini.

\section{Inflasi}

Inflasi merupakan kenaikan harga barangbarang yang bersifat umum dan terus-menerus. Dalam data yang diperoleh oleh peneliti dari laporan publikasi Bank Indonesia dan setelah data tersebut diolah maka dapat diperoleh bahwa data Inflasi mengalami fluktuasi, hal ini dapat dilihat pada tabel di bawah ini:

Tabel 2

Perkembangan Inflasi di Indonesia Tahun 2012-2017 (dalam \%)

\begin{tabular}{|c|c|c|c|c|c|c|}
\hline \multirow{2}{*}{ Bulan } & \multicolumn{6}{|c|}{ Tahun } \\
\hline & 2012 & 2013 & 2014 & 2015 & 2016 & 2017 \\
\hline Januari & 3,65 & 4,57 & 8,22 & 6,96 & 4,14 & 3,49 \\
\hline Februari & 3,56 & 5,31 & 7,75 & 6,29 & 4,42 & 3,83 \\
\hline Maret & 3,97 & 5,90 & 7,32 & 6,38 & 4,45 & 3,61 \\
\hline April & 4,50 & 5,57 & 7,25 & 6,79 & 3,60 & 4,17 \\
\hline Mei & 4,45 & 5,47 & 7,32 & 7,15 & 3,33 & 4,33 \\
\hline Juni & 4,53 & 5,90 & 6,70 & 7,26 & 3,45 & 4,37 \\
\hline Juli & 4,56 & 8,61 & 4,53 & 7,26 & 3,21 & 3,88 \\
\hline Agustus & 4,58 & 8,79 & 3,99 & 7,18 & 2,79 & 3,82 \\
\hline September & 4,31 & 8,40 & 4,53 & 6,83 & 3,07 & 3,72 \\
\hline Oktober & 4,61 & 8,32 & 4,83 & 6,25 & 3,31 & 3,58 \\
\hline November & 4,32 & 8,37 & 6,23 & 4,89 & 3,58 & 3,30 \\
\hline Desember & 4,30 & 8,38 & 8,36 & 3,35 & 3,02 & 3,61 \\
\hline
\end{tabular}

Sumber: Diolah dari berbagai sumber

Berdasarkan data yang ada pada tabel 2 di atas maka diperoleh informasi bahwa pada tahun 2012, 2013, 2014, 2015, 2016 dan 2017 Inflasi mengalami fluktuasi. Agar lebih jelas melihat perkembangan Inflasi tersebut, maka dapat dilihat pada gambar di bawah ini: 


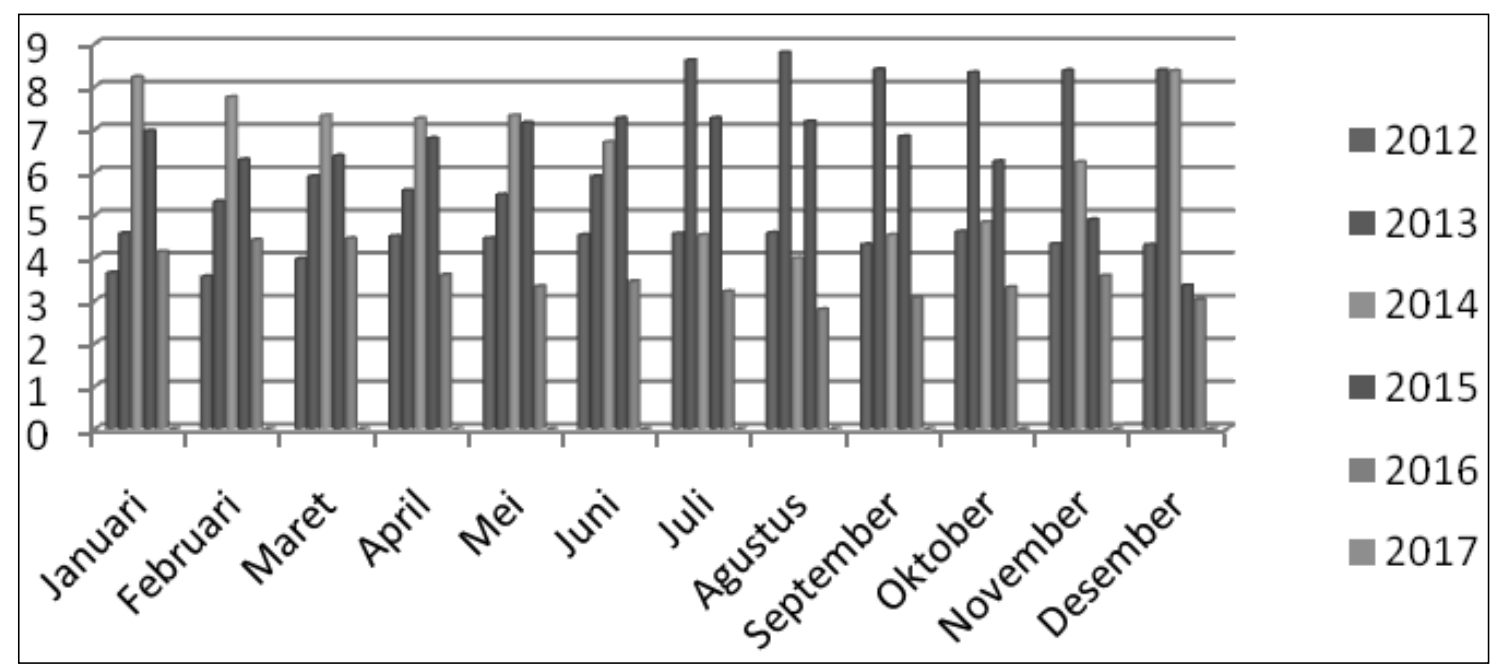

Gambar 1

Pertumbuhan Inflasi di Indonesia Tahun 012-2017 (Dalam \%) Sumber: Diolah dari berbagai sumber

\section{Bl rate}

BI rate adalah suku bunga kebijakan yang mencerminkan sikap atau stance kebijakan moneter yang ditetapkan oleh Bank Indonesia dan diumumkan kepada publik. Dari data yang diperoleh oleh peneliti dari laporan publikasi Bank Indonesia dan setelah data tersebut diolah maka dapat diperoleh bahwa data BI Rate mengalami fluktuasi. Adapun data perkembangan fluktuasi BI Rate adalah sebagai berikut:

Tabel 3

Pertumbuhan di BI Rate Indonesia Tahun 2012-2017 (Dalam \%)

\begin{tabular}{|c|c|c|c|c|c|c|}
\hline \multirow{2}{*}{ Bulan } & \multicolumn{6}{|c|}{ Tahun } \\
\hline & 2012 & 2013 & 2014 & 2015 & 2016 & 2017 \\
\hline Januari & 6,00 & 5,75 & 7,50 & 7,75 & 7,25 & 4,75 \\
\hline Februari & 5,75 & 5,75 & 7,50 & 7,50 & 7,00 & 4,75 \\
\hline Maret & 5,75 & 5,75 & 7,50 & 7,50 & 6,75 & 4,75 \\
\hline April & 5,75 & 5,75 & 7,50 & 7,50 & 6,75 & 4,75 \\
\hline Mei & 5,75 & 5,75 & 7,50 & 7,50 & 6,75 & 4,75 \\
\hline Juni & 5,75 & 6,00 & 7,50 & 7,50 & 6,50 & 4,75 \\
\hline Juli & 5,75 & 6,50 & 7,50 & 7,50 & 6,50 & 4,75 \\
\hline Agustus & 5,75 & 7,00 & 7,50 & 7,50 & 5,25 & 4,50 \\
\hline September & 5,75 & 7,25 & 7,50 & 7,50 & 5,00 & 4,25 \\
\hline Oktober & 5,75 & 7,25 & 7,50 & 7,50 & 4,75 & 4,25 \\
\hline November & 5,75 & 7,50 & 7,50 & 7,50 & 4,75 & 4,25 \\
\hline Desember & 5,75 & 7,50 & 7,75 & 7,50 & 4,75 & 4,25 \\
\hline
\end{tabular}

Sumber: Diolah dari berbagai sumber

Berdasarkan tabel 3 maka diperoleh informasi bahwa pada tahun 2012, 2013, 2014, 2015, 2016 jelas melihat perkembangan BI Rate tersebut, dan 2017 BI Rate mengalami fluktuasi. Agar lebih maka dapat dilihat pada gambar di bawah ini. 


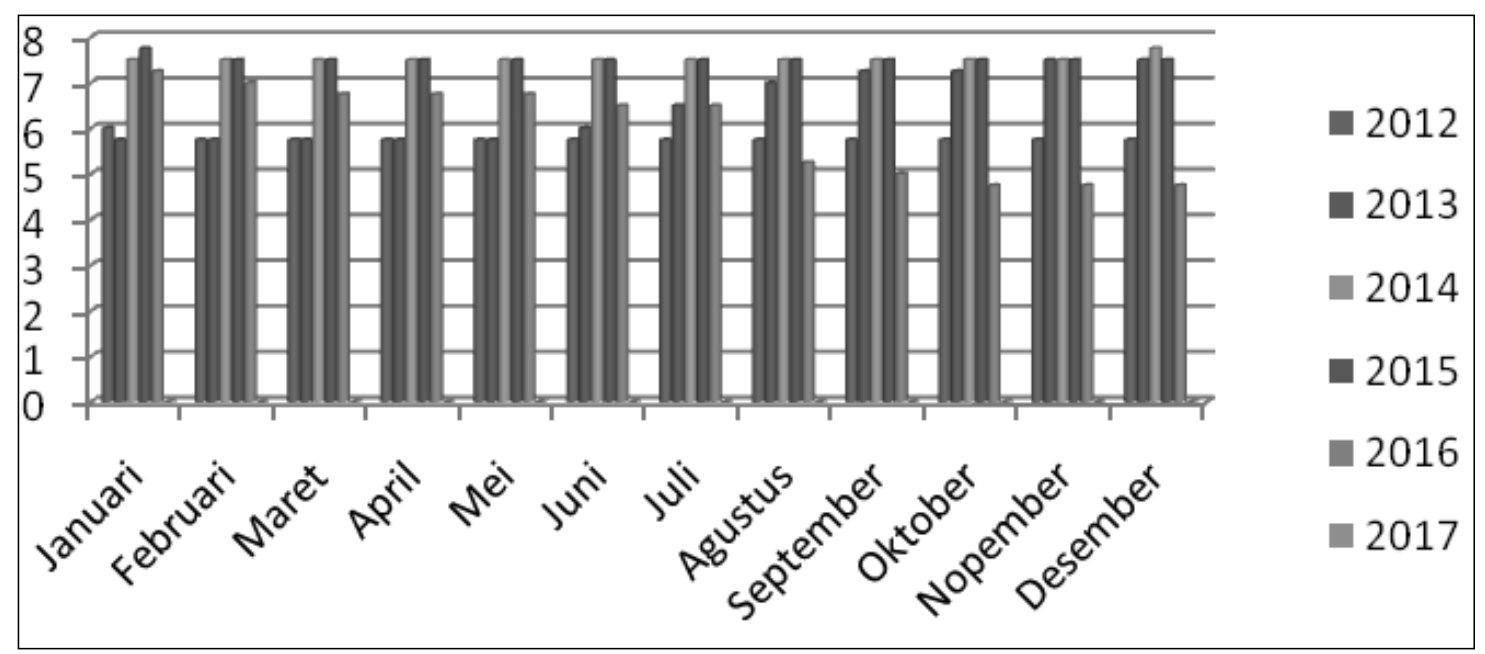

Gambar 2

Pertumbuhan BI Rate tahun 2012-2017 (Dalam \%) Sumber: Diolah dari berbagai sumber

\section{Nilai Tukar Rupiah}

Nilai tukar Rupiah adalah harga satu unit mata uang asing dalam mata uang domestik atau dapat juga dikatakan harga mata uang domestik terhadap mata uang asing. Dari data yang diperoleh oleh peneliti dari laporan publikasi Bank Indonesia dan setelah data tersebut diolah maka dapat diperoleh bahwa data nilai tukar Rupiah mengalami fluktuasi. Adapun data perkembangan fluktuasi nilai tukar Rupiah adalah sebagai berikut:

Tabel 4

Perkembangan Nilai Tukar Rupiah di Indonesia Tahun 2012-2017 (Dalam Rupiah)

\begin{tabular}{|l|l|l|l|r|r|r|}
\hline \multirow{2}{*}{ Bulan } & \multicolumn{7}{|c|}{ Tahun } \\
\cline { 2 - 7 } & $\mathbf{2 0 1 2}$ & $\mathbf{2 0 1 3}$ & $\mathbf{2 0 1 4}$ & $\mathbf{2 0 1 5}$ & $\mathbf{2 0 1 6}$ & $\mathbf{2 0 1 7}$ \\
\hline Jan & $9.000,00$ & $9.698,00$ & $12.226,00$ & $12.625,00$ & $13.846,00$ & $13.335,00$ \\
\hline Feb & $9.085,00$ & $9.667,00$ & $11.634,00$ & $12.863,00$ & $13.395,00$ & $13.347,00$ \\
\hline Mar & $9.180,00$ & $9.719,00$ & $11.404,00$ & $13.084,00$ & $13.276,00$ & $13.321,00$ \\
\hline April & $9.190,00$ & $9.722,00$ & $11.532,00$ & $12.937,00$ & $13.204,00$ & $13.327,00$ \\
\hline Mei & $9.565,00$ & $9.802,00$ & $11.611,00$ & $13.211,00$ & $13.615,00$ & $13.321,00$ \\
\hline Juni & $9.480,00$ & $9.929,00$ & $11.969,00$ & $13.332,00$ & $13.180,00$ & $13.319,00$ \\
\hline Juli & $9.485,00$ & $10.278,00$ & $11.591,00$ & $13.481,00$ & $13.094,00$ & $13.326,00$ \\
\hline Agust & $9.560,00$ & $10.924,00$ & $11.717,00$ & $14.027,00$ & $13.300,00$ & $13.351,00$ \\
\hline Sept & $9.588,00$ & $11.613,00$ & $12.212,00$ & $14.657,00$ & $12.998,00$ & $13.492,00$ \\
\hline Okt & $9.615,00$ & $11.234,00$ & $12.082,00$ & $13.639,00$ & $13.051,00$ & $13.572,00$ \\
\hline Nov & $9.605,00$ & $11.977,00$ & $12.196,00$ & $13.840,00$ & $13.563,00$ & $13.514,00$ \\
\hline Des & $9.670,00$ & $12.189,00$ & $12.440,00$ & $13.795,00$ & $13.436,00$ & $13.548,00$ \\
\hline
\end{tabular}

Sumber: Diolah dari berbagai sumber

Berdasarkan tabel 4 di atas dapat diketahui bahwa pada tahun 2012, 2013, 2014, 2015, 2016 dan 2017 nilai tukar Rupiah mengalami fluktuasi.
Agar lebih jelas melihat perkembangan nilai tukar Rupiah tersebut, maka dapat dilihat pada gambar di bawah ini: 


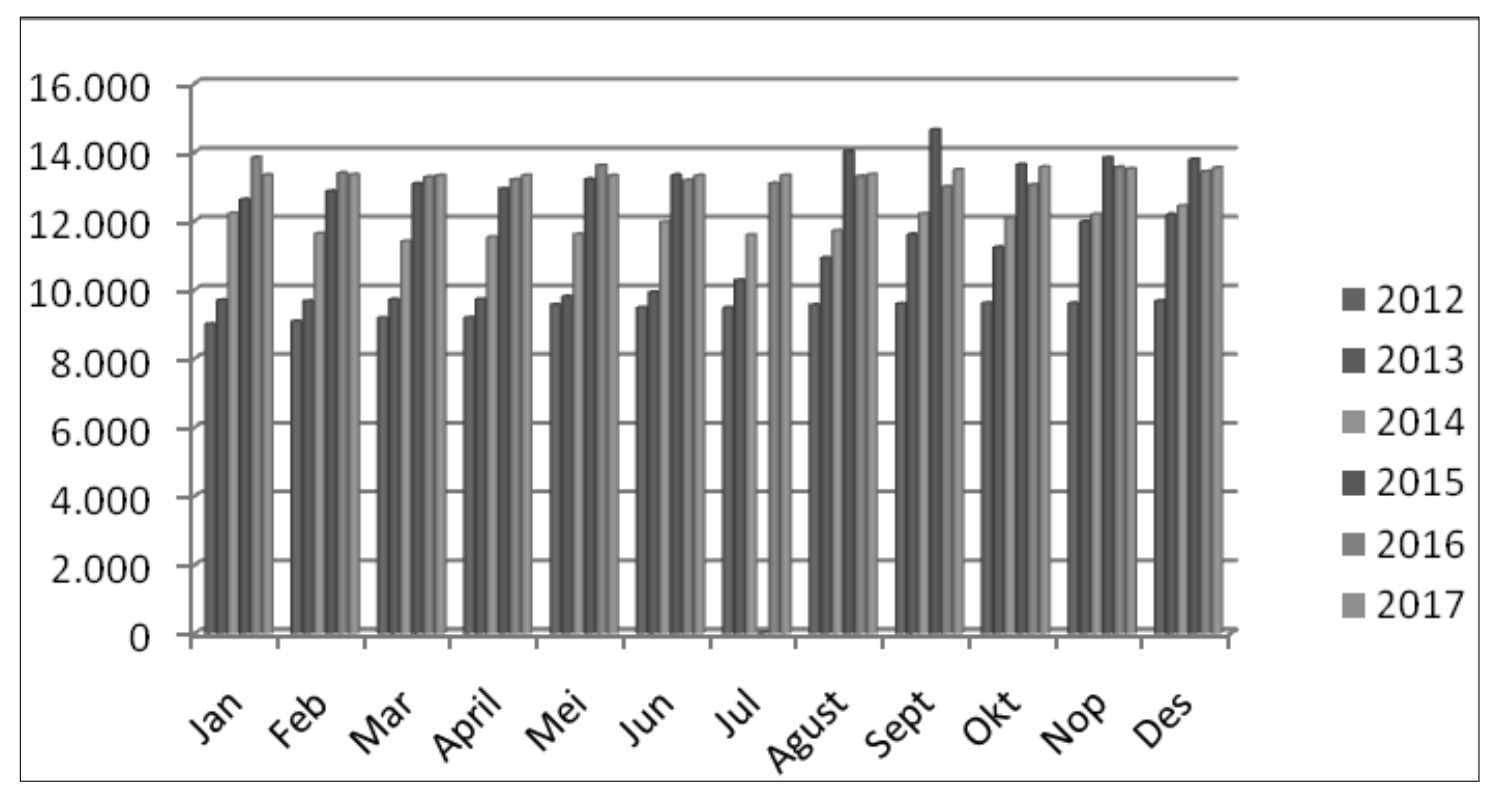

Gambar 3

Perkembangan Nilai Tukar Rupiah tahun 2012-2017 (Dalam Rupiah) Sumber: Diolah dari berbagai sumber

\section{Dana Pihak Ketiga}

Dana Pihak Ketiga adalah danayang bersumber dari masyarakat luas, baik itu masyarakat individu atau masyarakat dalam bentuk kelompok (badan usaha). Adapun data perkembangan Dana Pihak Ketiga Bank Umum Syariah dan Unit Usaha Syariah tahun 2012 sampai 2017 yang dipublikasikan oleh Otoritas Jasa Keuangan adalah sebagai berikut:

Tabel 5

Perkembangan Dana Pihak Ketiga Perbankan Syariah Indonesia Tahun 2012-2017 (Dalam Milyar Rupiah)

\begin{tabular}{|l|r|r|r|r|r|r|}
\hline \multirow{2}{*}{ Bulan } & \multicolumn{7}{|c|}{ Tahun } \\
\cline { 2 - 7 } & $\mathbf{2 0 1 2}$ & $\mathbf{2 0 1 3}$ & $\mathbf{2 0 1 4}$ & $\mathbf{2 0 1 5}$ & $\mathbf{2 0 1 6}$ & $\mathbf{2 0 1 7}$ \\
\hline Jan & 116,518 & 148,731 & 177,930 & 210,761 & 229,094 & 277,714 \\
\hline Feb & 114,616 & 150,795 & 178,154 & 210,297 & 231,820 & 281,084 \\
\hline Mar & 114,318 & 156,964 & 180,945 & 212,988 & 232,657 & 286,178 \\
\hline April & 114,018 & 158,519 & 185,508 & 213,973 & 233,808 & 291,889 \\
\hline Mei & 115,206 & 163,858 & 190,783 & 215,339 & 238,366 & 295,606 \\
\hline Juni & 119,279 & 163,966 & 191,594 & 213,477 & 241,336 & 302,013 \\
\hline Juli & 121,018 & 166,453 & 194,299 & 216,083 & 243,184 & 307,638 \\
\hline Agust & 123,673 & 170,222 & 195,959 & 216,356 & 244,843 & 309,006 \\
\hline Sep & 127,678 & 171,222 & 197,959 & 216,680 & 263,522 & 318,574 \\
\hline Okt & 134,453 & 174,018 & 207,121 & 219,478 & 264,678 & 319,124 \\
\hline Nop & 138,671 & 176,292 & 209,644 & 220,635 & 270,480 & 322,715 \\
\hline Des & 147,512 & 183,534 & 217,858 & 231,175 & 279,335 & 334,719 \\
\hline
\end{tabular}

Sumber: Diolah dari berbagai sumber

Dari tabel 5 di atas dapat kita lihat bahwa pada tahun 2012, 2013, 2014, 2015, 2016 dan 2017 Dana Pihak Ketiga mengalami fluktuasi.
Agar lebih jelas melihat perkembangan Dana Pihak Ketiga tersebut, maka dapat dilihat pada Gambar di bawah ini: 


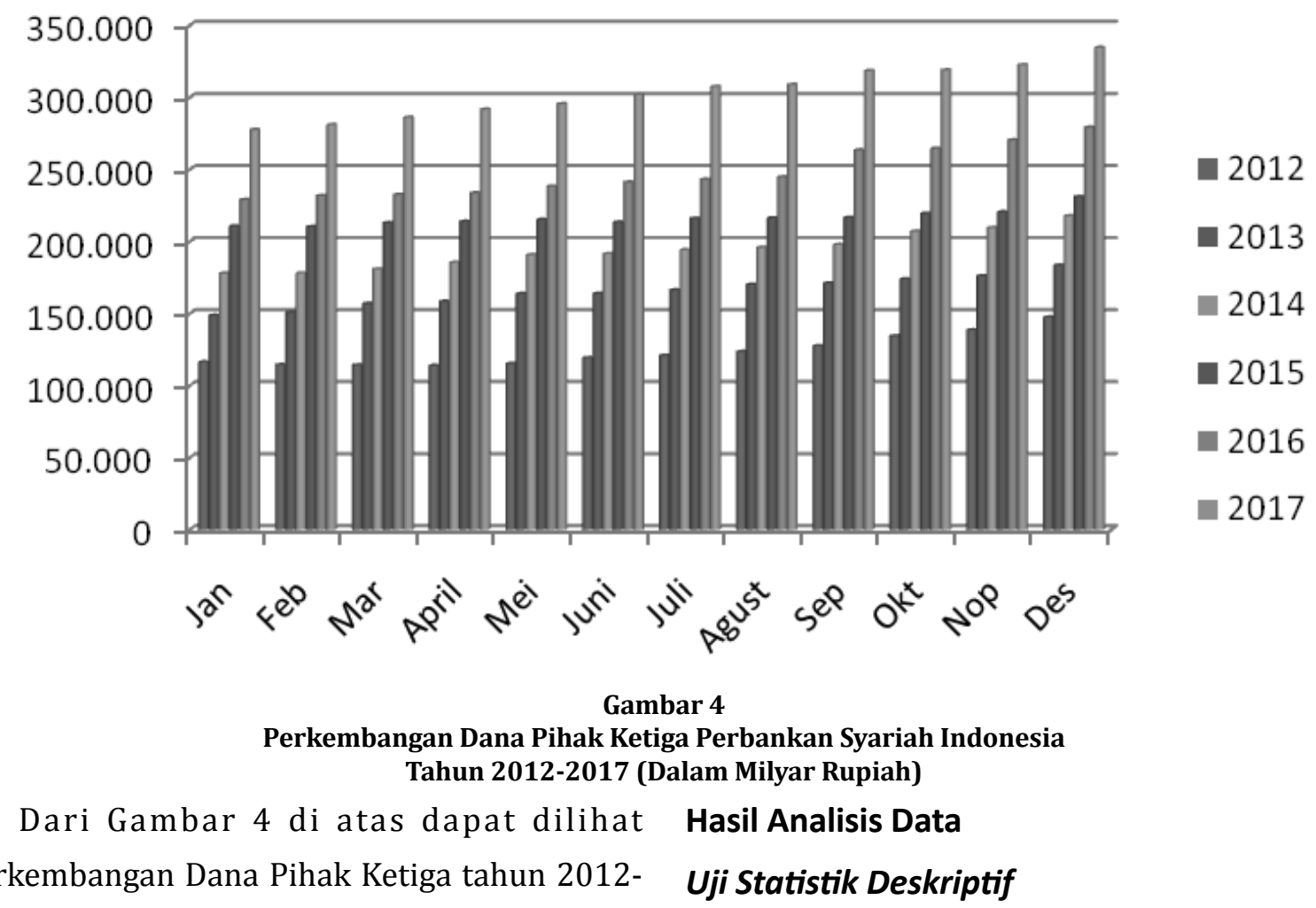

2017. Tahun 2012 pada bulan Februari sampai April Dana Pihak Ketiga menglami penurunan. Namun pada bulan Mei hingga bulan Desember Dana Pihak Ketiga selalu menglami peningkatan. Pada tahun 2013 Dana Pihak Ketiga selalu mengalami peningkatan setiap bulannya. Begitu juga pada tahun 2014 Dana Pihak Ketiga selalu menglami peningkatan setiap bulannya. Selanjutnya yaitu pada tahun 2015 pada bulan Februari Dana Pihak Ketiga mengalami penurunan dari tahun sebelumnya yaitu dari Rp 210.761,00 menjadi Rp 210.297,00. Dan pada bulan Maret Dana Pihak Ketiga kembali mengalami peningkatan menjadi Rp 212.988,00. Namun pada bulan Juni Dana Pihak Ketiga kembali mengalami penurunan. Tahun 2016 Dana Pihak Ketiga selalu mengalami peningkatan setiap bulannya. Pada tahun 2017 Dana Pihak Ketiga selalu mengalami peningkatan setiap bulannya.

Penelitian yang dilakukan oleh peneliti merupakan penelitian dengan data sekunder yang diperoleh dari laporan publikasi Bank Indonesia yaitu www.bi.go.id dan Otoritas Jasa Keuangan yaitu www.ojk.go.id. Peneliti menggunakan sampel sebanyak 72 samppel yang datanya diambil perbulan. Yaitu tingkat Inflasi, BI rate, nilai tukar Rupiah, dan Dana Pihak Ketiga yang diambil dari Januari 2012 sampai Desember 2017.

Inflasi merupakan kenaikan harga barangbarang yang bersifat umum dan terus-menerus. Adapun BI rate adalah suku bunga kebijakan yang mencerminkan sikap atau stance kebijakan moneter yang ditetapkan oleh Bank Indonesia dan diumumkan kepada publik. Sedangkan nilai tukar Rupiah adalah harga satu unit mata uang asing dalam mata uang domestik atau dapat juga dikatakan harga mata uang domestik terhadap mata uang asing. Dan Dana Pihak Ketiga adalah 
dana yang bersumber dari masyarakat luas, baik itu masyarakat individu atau masyarakat dalam bentuk kelompok (badan usaha). Berikut ini

Tabel 6

Deskriptif Data Penelitian

\begin{tabular}{|l|l|r|r|r|r|}
\hline \multicolumn{7}{|c|}{ Descriptive Statistics } \\
\hline & N & Minimum & Maximum & Mean & Std. Deviation \\
\hline DPK & 72 & 114018,00 & 334719,00 & 208589,9167 & 59399,27471 \\
\hline INFLASI & 72 & 2,79 & 8,79 & 5,2310 & 1,74103 \\
\hline BI RATE & 72 & 4,25 & 7,75 & 6,3090 & 1,15711 \\
\hline NILAI TUKAR RUPIAH & 72 & 9000,00 & 14657,00 & 12008,4861 & 1643,29219 \\
\hline Valid N (listwise) & 72 & & & & \\
\hline
\end{tabular}

Sumber: hasil penelitian (output SPSS versi 23, data diolah 2018)

Berdasarkan tabel 6 di atas dapat diketahui bahwa N merupakan jumlah sampel yang diambil peneliti dalam penelitian dari bulan Januari 2012 sampai Desember 2017 yang berjumlah 72 sampel. Dari tabel di atas diketahui bahwa nilai minimum dari variabel Inflasiadalah 2,79 persen nilai maksimumnya adalah 8,79 persen. Nilai rata-rata variabel Inflasi sebesar 5,2310 persen sedangkan nilai standar deviasi dari variabel Inflasi adalah 1,74103.

Variabel BI rate memiliki nilai minimum 4,25 persen, nilai maksimumnya adalah 7,75 persen. Nilai rata-rata variabel BI Rate sebesar 6,3090 persen sedangkan nilai standar deviasi dari variabel BI Rate adalah 1,15711. Sedangkan variabel Nilai Tukar Rupiah memiliki nilai minimum Rp. 9000,00, nilai maksimumnya adalah Rp. 14657,00. Nilai rata-rata variabel Nilai Tukar Rupiah sebesar Rp. 12008,4861. Sedangkan nilai standar deviasi dari variabel Nilai Tukar Rupiah adalah 1643,29219.

Tabel 7

Hasil Uji Koefisien Determinasi $\left(\mathrm{R}^{2}\right)$

Model Summary

\begin{tabular}{|c|r|r|r|r|}
\hline Model & R & R Square & Adjusted R Square & Durbin-Watson \\
\hline 1 &, $964^{\mathrm{a}}$ &, 930 &, 927 & 459 \\
\hline
\end{tabular}

1. Predictors: (Constant), NILAI TUKAR RUPIAH, BI RATE, INFLASI

2. Dependent Variable: DPK

Sumber: hasil penelitian (Output SPSS 23, data diolah 2018)

Pengaruh Inflasi, Bl Rate, dan Nilai Tukar Rupiah terhadap Dana Pihak Ketiga... | 103 
Berdasarkan hasil output SPSS model summary besarnya adjusted R square adalah 0,927 artinya variabel Inflasi, BI Rate dan Nilai Tukar Rupiah mampu menjelaskan variansi variabel Dana Pihak Ketiga sebesar 92,7 persen, sedangkan sisanya yaitu 7,3 persen dipegaruhi oleh variabel lain yang tidak dimasukkan dalam penelitian ini.

\section{b. Uji Parsial (Uji t)}

Uji t digunakan untuk mengetahui apakah dalam model regresi variabel independen seacara

Tabel 8

Uji Parsial (Uji t)

Coefficients $^{a}$

\begin{tabular}{|c|c|c|c|c|c|c|}
\hline & \multirow[t]{2}{*}{ Model } & \multicolumn{2}{|c|}{ Unstandardized Coefficients } & \multirow{2}{*}{$\begin{array}{c}\begin{array}{c}\text { Standardized } \\
\text { Coefficients }\end{array} \\
\text { Beta }\end{array}$} & \multirow[t]{2}{*}{$\mathbf{T}$} & \multirow[t]{2}{*}{ Sig. } \\
\hline & & B & Std. Error & & & \\
\hline \multirow{4}{*}{1} & (Constant) & $-31790,404$ & 17050,158 & & $-1,865$ & ,067 \\
\hline & INFLASI & 2789,181 & 1514,246 & ,082 & 1,842 & ,070 \\
\hline & BI RATE & $-25510,589$ & 2272,193 &,- 497 & $-11,227$ &, 000 \\
\hline & NILAI TUKAR RUPIAH & 32,205 & 1,180 & ,891 & 27,292 &, 000 \\
\hline
\end{tabular}

a. Dependent Variable: DPK

Sumber: hasil penelitian (Output SPSS 23, data diolah 2018)

\section{1) Inflasi terhadap Dana Pihak Ketiga}

a) Perumusan Hipotesis

$$
\begin{aligned}
\mathrm{H}_{\mathrm{o} 1}= & \text { Inflasi tidak berpengaruh } \\
& \text { terhadap Dana Pihak Ketiga } \\
\mathrm{H}_{\mathrm{a} 1}= & \text { Inflasi berpengaruh terhadap } \\
& \text { Dana Pihak Ketiga }
\end{aligned}
$$

b) Kesimpulan uji t atau uji parsial Inflasi.

Berdasarkan kriteria pengujian diatas dapat diketahui bahwa, $\mathrm{t}_{\text {hitung }}>\mathrm{t}_{\text {tabel }}$ $(1,842>1,667)$ maka $H_{o}$ ditolak, dan signifikansi $>0,05(0,070>0,05)$ maka $\mathrm{H}_{\mathrm{o}}$ diterima. Jadi dapat disimpulkan bahwa Inflasi tidak berpengaruh terhadap Dana Pihak Ketiga.

\section{2) BI Rate terhadap Dana Pihak Ketiga}

a) Perumusan Hipotesis parsial berpengaruh signifikan terhadap variabel dependen.

Dengan kata lain untuk mengetahui pengaruh masing-masing variabel independen terhadap variabel dependen. Untuk mengetahui apakah koefisien regresi signifikan atau tidak, maka digunakan uji T untuk menguji signifikansi konstanta dan variabel. Untuk mengetahui nilai $\mathrm{T}$ dapat dilihat pada tabel di bawah ini: 
tinggi persentase BI rate maka akan mengakibatkan penurunan Dana Pihak Ketiga, sebaliknya semakin rendah persentase BI rate maka akan mengakibatkan peningkatan Dana Pihak Ketiga.

\section{3) Nilai Tukar Rupiah terhadap Dana} Pihak Ketiga

a) Perumusan Hipotesis

$\mathrm{H}_{\mathrm{o} 1}=$ Nilai Tukar Rupiah tidak berpengaruh terhadap Dana Pihak Ketiga

$\mathrm{H}_{\mathrm{a} 1}=$ Nilai Tukar Rupiah berpengaruh terhadap Dana Pihak Ketiga

b) Kesimpulan uji t atau uji parsial Nilai Tukar Rupiah

Berdasarkan kriteria pengujian di atas dapat diketahui bahwa, $t_{\text {hitung }}>t_{\text {tabel }}$
$(27,292>1,667)$ maka $\mathrm{H}_{\mathrm{o}}$ ditolak. Dan signifikansi $<0,05(0,000<0,05)$ maka $\mathrm{H}_{\mathrm{o}}$ ditolak,jadi dapat disimpulkan bahwa Nilai Tukar Rupiah secara parsial berpengaruh signifikan terhadap Dana Pihak Ketiga. Nilai $\mathrm{t}_{\text {hitung }}$ positif artinya Nilai Tukar Rupiah memiliki pengaruh positif positif terhadap Dana Pihak Ketiga, yaitu jika Nilai Tukar Rupiah menguat maka Dana Pihak Ketiga akan meningkat.

\section{c. Uji Koefisien Regresi Secara Simultan (Uji F)}

Yaitu uji koefisien regresi secara bersamasama untuk menguji signifikansi pengaruh beberapa variabel independen terhadap variabel dependen. Pengujian menggunakan tingkat signifikansi 0,05. Untuk mengetahui nilai F dapat dilihat melalui tabel di bawah ini:

Tabel 9

Uji F

ANOVA $^{\mathrm{a}}$

\begin{tabular}{|l|l|r|r|r|r|r|}
\hline \multicolumn{2}{|c|}{ Model } & \multicolumn{1}{c|}{ Sum of Squares } & Df & \multicolumn{1}{c|}{ Mean Square } & F & Sig. \\
\hline \multirow{4}{*}{1} & Regression & 232972700372,550 & 3 & 77657566790,850 & 301,157 &, $000 \mathrm{~b}$ \\
\cline { 2 - 8 } & Residual & 17534741968,950 & 68 & 257863852,485 & & \\
\cline { 2 - 8 } & Total & 250507442341,500 & 71 & & & \\
\hline
\end{tabular}

a. Dependent Variable: DPK

b. Predictors: (Constant), Nilai Tukar Rupiah, Bi Rate, Inflasi

Sumber: hasil penelitian (Output SPSS 23, data diolah 2018)

Langkah-langkah Uji Koefisien Regresi Secara

Simultan (Uji F) adalah sebagai berikut:

\section{1) Perumusan Hipotesis}

$\mathrm{H}_{\mathrm{o}}=$ inflasi, BI rate dan nilai tukar Rupiah tidak berpengaruh signifikan terhadap Dana Pihak Ketiga

$\mathrm{H}_{\mathrm{a}}=$ inflasi, BI rate dan nilai tukar Rupiah berpengaruh signifikan terhadap Dana

\section{2) Kesimpulan uji F}

Berdasarkan kriteria pengujian di atas dapat diketahui bahwa, $\mathrm{F}_{\text {hitung }}>\mathrm{F}_{\text {tabel }}(301,157>3,16)$ maka $\mathrm{H}_{\mathrm{o}}$ ditolak. Dan signifikansi $<0,05(0,000$ $<0,05$ ) maka $\mathrm{H}_{\mathrm{o}}$ ditolak, jadi dapat disimpulkan bahwa Inflasi, BI Rate dan Nilai Tukar Rupiah secara simultan berpengaruh terhadap Dana Pihak Ketiga. Pihak Ketiga 


\section{Hasil Regresi Berganda}

Uji ini digunakan untuk menganalisis hubungan antara variabel dependen dengan variabel independen. Tujuan dari analisis ini adalah untuk mengetahui signifikansi pengaruh variabel independen terhadap variabel dependen, yaitu apakah masing-masing variabel Inflasi, BI Rate dan Nilai Tukar Rupiah berhubungan positifatau negatif dan untuk memprediksi nilai dari Dana Pihak Ketiga apabila nilai variabel Inflasi, BI Rate dan Nilai Tukar Rupiah mengalami kenaikan dan penurunan. Berikut adalah hasil dari analisis berganda.

Tabel 10

Uji Regresi Berganda Coefficients $^{\mathrm{a}}$

\begin{tabular}{|c|c|c|c|c|c|}
\hline \multirow{2}{*}{\multicolumn{2}{|c|}{ Model }} & \multirow{2}{*}{$\begin{array}{c}\begin{array}{c}\text { Unstandardized } \\
\text { Coefficients }\end{array} \\
\text { B }\end{array}$} & \multirow{2}{*}{$\begin{array}{c}\begin{array}{c}\text { Standardized } \\
\text { Coefficients }\end{array} \\
\text { Beta }\end{array}$} & \multicolumn{2}{|c|}{ Collinearity Statistics } \\
\hline & & & & Tolerance & VIF \\
\hline \multirow{4}{*}{1} & (Constant) & $-31790,404$ & & & \\
\hline & INFLASI & 2789,181 & ,082 & ,523 & 1,914 \\
\hline & $\mathrm{BI}$ RATE & $-25510,589$ &,- 497 &, 525 & 1,903 \\
\hline & NILAI TUKAR RUPIAH & 32,205 & 891 & 966 & 1,035 \\
\hline
\end{tabular}

a. Dependent Variable: DPK

Sumber: hasil penelitian (Output SPSS 23, data diolah 2018)

Dapat diartikan sebagai berikut:

a. Konstanta (a) sebesar $-31790,404$, artinya jika variabel Inflasi $\left(\mathrm{X}_{1}\right)$, BI Rate $\left(\mathrm{X}_{2}\right)$ dan Nilai Tukar Rupiah $\left(\mathrm{X}_{3}\right)$ nilainya 0, maka Dana Pihak Ketiga nilainya Rp -31790,404.

b. Nilai koefisien regresi variabel Inflasi (b1) bernilai positifyaitu 2789,181, ini dapatdiartikan bahwa jika variabel inflasi meningkat $1 \%$ dan variabel lain tetap maka DPK akan mengalami peningkatan sejumlah Rp. 2789,181 Milyar.

c. Nilai koefisien regresi variabel BI Rate (b2) bernilai negatif yaitu $-25510,589$, ini dapat diartikan bahwa jika nilai BI Rate diasumsikan naik 1 persen dan variabel lain tetap maka Dana Pihak Ketiga akan mengalami penurunan sebesar Rp 25510,589 Milyar.

d. Nilai koefisien regresi variabel Nilai Tukar Rupiah (b3) bernilai positif yaitu 32,205, ini dapat diartikan bahwa setiap peningkatan
Nilai Tukar Rupiah sebesar Rp 1 maka akan meningkatkan Dana Pihak Ketiga sebesar Rp 32,205 Milyar dengan asumsi variabel independen lain nilainya tetap.

\section{Hasil Penelitian}

Penelitian yang dilakukan oleh peneliti adalah dengan menggunakan data sekunder yang diambil dari website resmi Bank Indonesia dan Otoritas Jasa Keuangan yang berjudul “Pengaruh Inflasi, BI Rate, dan Nilai Tukar Rupiah terhadap Dana Pihak Ketiga pada Perbankan Syariah Tahun 2012-2017. Setelah melalui berbagai analisis data terhadap model, maka dapat disimpulkan bahwa persamaan regresi yang digunakan telah cukup baik karena telah memenuhi persyaratan BLUE (Best Linear Unbiased Estimator) yaitu data yang diuji berdistribusi normal, tidak terdapat multikolinearitas, tidak terdapat autokorelasi dan tidak terdapat heteroskedastisitas. 
Pengaruh Inflasi Terhadap Dana Pihak Ketiga pada Perbankan Syariah Tahun 2012-2017.

Berdasarkan hasil penelitian yang dilakukan peneliti dengan menggunakan program SPSS versi 23 , maka diperoleh nilai $t_{\text {hirung }}$ variabel Inflasi adalah 1,842 dan $t_{\text {tabel }}$ yang diperoleh sebesar 1,667. $t_{\text {hitung }}>t_{\text {tabel }}(1,842>1,667)$ maka $\mathrm{H}_{\mathrm{o}}$ ditolak, dan signifikansi $>0,05(0,070>0,05)$ maka $\mathrm{H}_{\mathrm{o}}$ diterima. Jadi dapat disimpulkan bahwa Inflasi tidak berpengaruh terhadap Dana Pihak Ketiga.

Hasil penelitian ini tidak sesuai dengan pendapat Aulia Pohan yang menyatakan bahwa Laju Inflasi yang tinggi dan tidak terkendali dapat mengganggu upaya perbankan dalam pengerahan dana masyarakat (Pohan, 2008: 52). Namun pada bank syariah kenaikan Inflasi tidak menyebabkan penurunan jumlah Dana Pihak Ketiga. di bank syariah. Kemudian penelitian ini didukung oleh penelitian Aulia Putri Siregar dimana Inflasi tidak berpengaruh terhadap Dana Pihak Ketiga.

\section{Pengaruh BI Rate Terhadap Dana Pihak Ketiga pada Perbankan Syariah Tahun 2012-2017.}

Hasil penelitian ini menunjukkan bahwa BI Rate memiliki pengaruh negatif signifikan terhadap Dana Pihak Ketiga. Hal ini dapat dibuktikan dengan nilai $-\mathrm{t}_{\text {hitung }}<-\mathrm{t}_{\text {tabel }}(-11,227<$ $-1,667)$ dan signifikansi $<0,05(0,000<0,05)$ yang artinya BI Rate memiliki hubungan yang terbalik dengan Dana Pihak Ketiga. Yaitu jika BI Rate meningkat maka Dana Pihak Ketiga menurun dan sebaliknya jika BI Rate mengalami penurunan maka Dana Pihak Ketiga meningkat. Dengan kata lain, berdasarkan hipotesis maka $\mathrm{H}_{\mathrm{o} 2}$ ditolak.

Hasil penelitian ini sesuai dengan teori yang menyatakan bila terjadi bagi hasil pendanaan syariah lebih kecil dari tingkat bunga di pasar konvensional maka dapat berdampak pada peningkatan risiko likuiditas sebagai akibatnya nasabah dapat menarik dana dari bank syariah dan berpindah ke bank konvensional (Karim,2004: 273). Kemudian penelitian ini didukung oleh penelitian Friska Julianti dimana BI Rate berpengaruh negatif terhadap Tabungan Mudharabah (Julianti, Skripsi 2013: 84)

\section{Pengaruh Nilai Tukar Rupiah Terhadap Dana Pihak Ketiga pada Perbankan Syariah Tahun 2012-2017.}

Hasil penelitian ini menunjukkan bahwa Nilai Tukar Rupiah memiliki pengaruh positif terhadap Dana Pihak Ketiga. Hal ini dapat dibuktikan $t_{\text {hitung }}>t_{\text {tabel }}(27,292>1,667)$ dan signifikansi $<$ $0,05(0,000<0,05)$ artinya Nilai Tukar Rupiah berpengaruh positif terhadap Dana Pihak Ketiga. Yaitu jika Nilai Tukar Rupiah menguat maka Dana Pihak Ketiga akan meningkat begitu juga sebaliknya jika Nilai Tukar Rupiah melemah maka Dana Pihak Ketiga akan menurun. Dengan kata lain, berdasarkan hipotesis maka $\mathrm{H}_{\mathrm{o} 3}$ ditolak.

Penelitian ini didukung oleh teori Aulia Pohan dalam buku Potret Kebijakan Moneter yaitu Adanya ekspektasi masyarakat tentang melemahnya nilai Rupiah dapat mengakibatkan berkurangnya kepercayaan masyarakat terhadap Rupiah yang kemudian akan mendorong terjadinya spekulasi di pasar valuta asing. Keadaan ini akan mengurangi tersedianya dana masyarakat yang dapat dihimpun oleh perbankan untuk disalurkan ke sektor yang produktif (Pohan, 2008: 56.). Selain itu penelitian ini juga didukung oleh penelitian Aulia Putri Siregar 
dimana Nilai Tukar Rupiah berpengaruh positif terhadap Dana Pihak Ketiga.

\section{Pengaruh Inflasi, BI Rate dan Nilai Tukar Rupiah Secara Simultan Terhadap Dana Pihak Ketiga pada Perbankan Syariah Tahun 2012-2017.}

Berdasarkan hasil penelitian yang dilakukan peneliti dapat disimpulkan dalam uji simultan (uji F) bahwa variabel bebas terhadap variabel terikat maka diperoleh Inflasi, BI Rate dan Nilai Tukar Rupiah secara simultan memiliki pengaruh yang terhadap Dana Pihak Ketiga. Hal tersebut dibuktikan dengan nilai $\mathrm{F}_{\text {hitung }}>\mathrm{F}_{\text {tabel }}(301,157>$ $3,16)$ dan signifikansi $<0,05(0,000<0,05)$. Dengan kata lain, berdasarkan hipotesis maka $\mathrm{H}_{\mathrm{o}}$ ditolak dan $\mathrm{H}_{\mathrm{a}}$ diterima. Hasil penelitian ini didukung dengan penelitian yang dilakukan oleh Friska Julianti bahwa Inflasi, BI Rate dan Nilai Tukar Rupiah secara simultan berpengaruh terhadap Dana Pihak Ketiga.

Adapun Faktor-faktor yang mempengaruhi Dana Pihak Ketiga yaitu: kondisi perekonomian masyarakat Indonesia seperti terjadinya Inflasi dan melemahnya Nilai Tukar Rupiah, kondisi pemerintahan, kondisi pasar uang dan pasar modal, kebijakan pemerintah dan juga peraturan Bank Indonesia seperti BI Rate dan Jumlah Uang Beredar.

\section{PENUTUP}

Hasil penelitian ini menyimpulkan bahwa nilai koefisien determinasi $\left(\mathrm{R}^{2}\right)$ sebesar 0,927 artinya inflasi, BI rate dan nilai tukar Rupiah mampu menjelaskan variasi variabel Dana Pihak Ketiga sebesar 92,7 persen. Adapun sisanya 7,3 persen dijelaskan oleh variabel lain yang tidak dimasukkan dalam penelitian ini. Hasil penelitian ini menunjukkan secara parsial menyatakan bahwa Inflasi memiliki $t_{\text {hitung }}>t_{\text {tabel }}$ atau 1,842 > 1,667 yang artinya Inflasi berpengaruh terhadap Dana Pihak Ketiga. BI Rate memiliki $-\mathrm{t}_{\text {hitung }}<$ $-t_{\text {tabel }}(-11,227<-1,667)$ yang artinya BI Rate berpengaruh terhadap Dana Pihak Ketiga. Nilai Tukar Rupiah berpengaruh terhadap Dana Pihak Ketiga dengan $t_{\text {hitung }}>t_{\text {tabel }}(27,292>1,667)$. Inflasi, BI Rate dan Nilai Tukar Rupiah secara simultan memiliki pengaruh yang signifikan terhadap Dana Pihak Ketiga. Hal tersebut dibuktikan dengan nilai $\mathrm{F}_{\text {hitung }}>\mathrm{F}_{\text {tabel }}(301,157>3,16)$.

\section{DAFTAR KEPUSTAKAAN}

Arikunto, Suharsimi, 2006. Prosedur Penelitian: Suatub Pendekatan Praktek. Jakarta: Rinekan Cipta.

Aruan, Novarita, 2013. Pengaruh BI Rate Terhadap Dana Pihak Ketiga Pada PT Bank Rakyat Indonesia (Persero) TBK Unit Tanjung Anom Periode Januari 2011 - Desember 2012. (Skripsi: Politeknik Negeri Medan)

Asnawi, Nur dan Masyhuri, 2011. Metodologi Riset Manajemen Pemasaran. Malang: UIN Maliki Press.

Dewi, Gemala, 2007. Aspek-Aspek Hukum dalam Perbankan dan Perasuransian Syariah di Indonesia. Jakarta: Kencana Prenada Media Group.

Harahap, Sofyan S., dkk., 2004. Akuntansi Perbankan Syariah. Jakarta: LPPE Usakti.

Ismail, 2011. Perbankan Syariah. Jakarta: Kencana Prenadamedia Group 
Julianti, Friska, 2013. Analisis Pengaruh Inflasi, Nilai Tukar, dan BI Rate Terhadap Tabungan Mudharabah Pada Perbankan Syariah. (Skripsi: Universitas Islam Negeri Sultan Syarif Hidayatullah Jakarta)

Karim, Adiwarman A, 2011. Ekonomi Makro Islam. Jakarta: Rajawali Press.

, 2004. Bank Islam Analisis Fiqih dan Keuangan. Jakarta: PT RajaGrapindo Persada.

Kuncoro, Mudrajad, 2009. Metode Riset untuk Bisnis dan Ekonomi. Jakarta: Erlangga

Mankiw, N. Gregory, 2006. Makroekonomi, Jakarta: Erlangga

Panorama, Maya, "Pengaruh Pertumbuhan Ekonomi, Inflasi, Jumlah Uang Beredar (M2) dan BI Rate Terhadap Tabungan Mudharabah Pada Perbankan Syariah Di Indonesia Periode 20052014", Jurnal I-Economic Vol. 2. No.1 Juli 2016.

Pohan, Aulia, 2008. Potret Kebijakan Moneter Indonesia. Jakarta: PT Raja Grafindo Persada. Pramesti, Getut, 2014. Kupas Tuntas Data Penelitian dengan SPSS 22. Jakarta: PT Elex Media Komputindo.
Priyatno, Dwi, 2017. Panduan Praktis Olah Data Menggunakan SPSS. Jakarta: ANDI.

Rahardja, Prathama dan Mandala Manurung, 2008. Pengantar Ilmu Ekonomi (Mikroekonomi dan Makroekonomi). Jakarta: Fakultas Ekonomi Universitas Indonesia.

Simorangkir, Iskandar dan Suseno, 2004. Sistem dan Kebijakan Nilai Tukar. Jakarta: Pusat Pendidikan dan Kebanksentralan.

Teguh, Muhammad, 2005. Metodologi Penelitian Ekonomi. Jakarta: PT. RajaGrafindo Persada.

Undang-Undang Nomor 21 tahun 2008 tentang Perbankan Syariah

Undang-Undang Nomor 10 Tahun 1998 tentang Perubahan Atas Undang-Undang Nomor 7 Tahun 1992 tentang Perbankan.

Rivai, Veithzal dan Arviyan, 2010. Islamic Banking: SebuahTeori, Komsep, dan Aplikasi. Jakarta: PT Bumi Aksara.

www.bi.go.id

www.ojk.go.id 